\title{
Latin American scientific contribution to ecology
}

\section{JULIANA WOJCIECHOWSKI ${ }^{1}$, FERNANDA CESCHIN ${ }^{2}$, SUELEN C.A.S. PERETO ${ }^{1}$, LUIZ G.S. RIBAS ${ }^{3}$, LUIS A.V. BEZERRA ${ }^{1}$, JAQUELINE DITTRICH ${ }^{2}$, TADEU SIQUEIRA ${ }^{4}$ and ANDRÉ A. PADIAL ${ }^{1,2}$}

\author{
${ }^{1}$ Pós-Graduação em Ecologia e Conservação, Universidade Federal do Paraná, Av. Coronel \\ Francisco H. dos Santos, 100, Jardim das Américas, 81531-990 Curitiba, PR, Brazil \\ ${ }^{2}$ Pós-Graduação em Ecologia de Ambientes Aquáticos Continentais, Universidade Estadual de \\ Maringá, Av. Colombo, 5790, Jardim Universitário, 87020-900 Maringá, PR, Brazil \\ ${ }^{3}$ Pós-Graduação em Ecologia e Evolução, Universidade Federal de Goiás, Av. \\ Esperança, s/n, Campus Samambaia, 74690-900 Goiânia, GO, Brazil \\ ${ }^{4}$ Universidade Estadual Paulista Júlio de Mesquita Filho, Instituto de Biociências de Rio Claro, \\ Departamento de Ecologia, Av. 24 A, 1515, Bela Vista, 13506-900 Rio Claro, SP, Brazil
}

Manuscript received on August 23, 2016; accepted for publication on January 27, 2017

\begin{abstract}
Latin America embodies countries of special interest for ecological studies, given that areas with great value for biodiversity are located within their territories. This highlights the importance of an evaluation of ecological research in the Latin America region. We assessed the scientific participation of Latin American researchers in ecological journals, patterns of international collaboration, and defined the main characteristics of the articles. Although Latin American publications have increased in fourteen years, they accounted up to $9 \%$ of publications in Ecology. Brazil leaded the scientific production in Latin America, followed by Argentina and Mexico. In general, Latin American articles represented a low percentage of most journals total publication, with particularly low expression in high impact-factor journals. A half of the Latin American publications had international collaboration. Articles with more than five authors and with international collaboration were the most cited. Descriptive studies, mainly based in old theories, are still majority, suggesting that Ecology is in a developing stage in Latin America.
\end{abstract}

Key words: article citations, international collaboration, journal impact factor, Neotropics, research policies, scientometrics.

\section{INTRODUCTION}

The overall scientific production of Latin American countries rose almost 200 percent between 1988 and 2001 (Hill 2004). Especially in the last two decades, the Brazilian scientific output quintupled (Van Noorden 2014) and the Argentine number of

Correspondence to: Juliana Wojciechowski

E-mail: julianawoj@gmail.com science doctorates increased tenfold (Catanzaro et al. 2014). Despite this robust increase, the contribution of these countries to the world scientific production is still low (Hermes-Lima et al. 2007) when compared to Europe and USA, which contribute with more than $30 \%$ each to worldwide publications (Glänzel et al. 2006). In addition, studies carried by Latin American (LA hereafter) authors receive much less citations than others 
carried out by authors from developed countries of Asia, Europe, North America and Oceania (Hermes-Lima et al. 2007). For example, Brazil ranked first in Latin America and $17^{\text {th }}$ in the rank among 146 countries in terms of overall scientific production, but drops off to the $91^{\text {st }}$ position in terms of citation per article (data from a 10-year country ranking of ISI Essential Science Indicators consulted in June 2016; In-Cites 2006). In South America, the highest citation impact weighted by research belongs to Peru, whereas two-thirds of South America's science personnel are in Brazil and the highest proportion of researchers per workers belongs to Argentina (Van Noorden 2014). Socio-economic and political instability, inertial effect of dictatorial regimes and language barriers are possibly the main reasons accounting for the relatively low scientific production and impact of the research conducted in LA countries (Catanzaro et al. 2014).

Even so, areas of special interest for ecological studies are located in LA countries, since within their territory there are seven out of 25 hotspots for biodiversity conservation priorities (Myers et al. 2000). Latin America is the most complex ecological area on Earth considering its primary productivity, biotic and ecosystem-level diversities (Toledo and Castillo 1999). Furthermore, LA habitats are facing several environmental problems such as deforestation, inefficient land-use practices, biodiversity loss, contamination of surface waters, depletion of aquifers and soil erosion (Martínez et al. 2006). Thus, the evaluation of ecological research conducted in Latin America is useful to inform policy makers and support management efforts aiming mitigation of environmental pressure and conservation of biodiversity and natural resources (Martínez et al. 2006). Thereby, the development of Ecology as a science must be a priority to LA researchers due to high anthropogenic alterations on natural environments (Toledo and Castillo 1999).
Scientific production on a particular research area reveals its trends and gaps (Verbeek et al. 2002). Several studies have evaluated Latin American scientific production in fields such as Conservation Biology (Galindo-Leal 2000), Medical Plant Sciences (Calixto 2005), Social Sciences and Public Health (Nunes 2006), Biochemistry and Physiology (Hermes-Lima and Navas 2006), health and several sub-fields of Medical Sciences (e.g., Pellegrini Filho et al. 1997, Weisinger and Bellorín-Font 1999, Falagas et al. 2006). Studies conducted in Latin America had an important role for the development of contemporary ecological knowledge. For example, several founders of modern Ecology, Biogeography and Evolution (including Charles Darwin, Alfred R. Wallace and Alexander von Humbolt) were attracted to this region due to its unique environmental diversity and evolutionary history (Martínez et al. 2006). Additionally, it is interesting to mention that Eugene Warming, considered by Arthur Tansley as "the father of Plant Ecology" (Godwin 1977) developed his most prominent research in Central Brazil. Even so, Ecology as a formal discipline emerged in Latin America in the last century, and only in the last years it is definitely gaining attention (Martínez et al. 2006). Latin America contributes worldwide with important and relevant researchers such as Eduardo H. Rapoport, an important Argentinean ecologist in the field of the Biogeography and Macroecology (see Rapoport's rule reported by Stevens 1989). Therefore, it is time for a critical evaluation of the Latin American scientific contribution to Ecology.

Here, we analyzed the participation of LA authors in Ecology from 2000 to 2014. Our study had two main objectives: to evaluate the general trends of scientific articles from LA authors (According to definition of Latin American Network Information Center-LANIC http://www1.lanic.utexas.edu/; see Appendix S1 - Supplementary Material) in Ecology during the last fourteen years and to identify the 
main characteristics of ecological studies in the region. Considering the first goal, we analyzed the temporal trends of LA scientific publication, the characteristics of journals in which LA researches published their works, the main international cooperation and their role on the scientific impact of LA researches. Considering the second goal, we quantified the main habitats, levels of ecological organization, response variables (organism or object studied), data organization approaches (e.g., experiment, survey or modeling), and theoretical approaches used by Latin Americans in ecological studies. In this case, we compared two journals: "Journal of Tropical Ecology", with clear focus to tropical research, where most LA countries are located; and "Ecology Letters", with no focus to a specific geographic region.

We presented a framework of Latin America scientific investigations in Ecology that reveals future perspectives on nature's conservation and management. Developing science in emerging regions is essential to guide worldwide policymakers' decisions, aiming to conserve nature at the global level.

\section{MATERIALS AND METHODS}

\section{DATABASE USED}

We analyzed 80 journals indexed by ISI's Web of Science ${ }^{\circledR}$ (www.isiknowledge.com), within the "Ecology" subject category (http://scientific. thomsonreuters.com/cgi-bin/jrnlst/jlsubcatg. cgi? $\mathrm{PC}=\mathrm{K}$ ). This list comprised journals with more general scope (e.g., "Oikos" and "Ecology"), journals where Ecology is focused along with zoological, botanical and geographical issues (e.g., "Journal of Animal Ecology" and "Journal of Biogeography"), and journals with an applied approach (e.g., "Journal of Applied Ecology" and "Ecological Applications"). In March $18^{\text {th }} 2015$, we recorded 12,673 articles published from 2000 to 2014 , in which at least one author was from LA.
We compiled into a single database the articles' title, abstract, authors' countries, authors' names, publication year, journal title, 2014's impact factor (JCR-2014), and the frequency of citation. The list of the analyzed journals (80), their impact factors, and the percentage of articles from LA authors per journal are detailed in Appendix S2. We opted to analyze only English written manuscripts, which were published in journals with worldwide circulation, to better understand the contribution of LA researches to worldwide Ecology.

\section{DATA ANALYSIS}

\section{General trends of LA scientific publication}

We firstly analyzed the percentage of articles authored by at least one researcher from LA. It is important to emphasize that we considered as LA authors those authors who were affiliated to Latin American institutions, regardless their nationality. This percentage was plotted against the total scientific production in the selected journals versus publication years. Therefore, we could visualize temporal trends in LA publications after controlling for the increase in published studies. Moreover, to identify which country had the fastest growth rate in terms of scientific production, we plotted the percentage of articles of authors from each country separately versus publication years. We also plotted the percentage of LA articles in the period of 20002014 against the 2014 Impact Factor (JCR-2014) of journals in which they were published.

We classified the articles according to different types of co-authorship to evaluate international collaboration as follows: (a) NonLA-LA - articles in which the first author was from a Non-Latin American country and all the co-authors were from Latin America; (b) LA-NonLA - articles in which the first author was from Latin America and all the co-authors were from Non-Latin American countries; (c) LA-LA - articles in 
which the first author was from Latin America and all the co-authors were from Latin American countries, at least one co-author from a different Latin American country from the first author; (d) LA-Both - articles in which the first author was from Latin America and there was at least one coauthor from Latin America and another one from a Non-Latin American country; (e) NonLA-Both - articles in which the first author was from a NonLatin America country and there were co-authors from Latin American and Non-Latin American countries; and (f) LA-None - only authors from the same Latin American country, i.e., articles that had no international co-authorship. We then evaluated the effect of co-authorship and number of authors on citation counts by using an Analysis of Covariance (ANCOVA). Considering that the age of publication affects intrinsically the citation of the papers (Gingras et al. 2008), this variable was treated as a co-variable in ANCOVA. We evaluated which cooperation type was mostly associated with high citation of the articles by comparing the slopes or the intercept of the linear regression (depending on the homogeneity of slopes analyses). We did the same considering number of authors versus article citation. Higher citations along the time span were associated to higher absolute values of slopes (in case of non-homogeneous slopes) or intercepts (in case of homogeneous slopes).

\section{Characteristics of Latin American scientific production}

In order to describe Latin American publication in Ecology, we analyzed the abstracts of all Latin American articles published in two journals in our database: "Journal of Tropical Ecology" (JTE; 1078 articles, Impact factor $2014=0.904)$ and "Ecology Letters" (ECL; 2086 articles, Impact factor $=10.689)$. We considered these journals representatives of the publications, since they have numerous articles. In addition, it would be roughly impracticable to analyze the abstracts of all articles of the selected database. Also, JTE have specific focus on tropical region, where most LA countries are located; whereas ECL does not have geographic bias.

We analyzed the articles regarding environments and ecosystems under study, levels of ecological organization, organism or variable on focus, data organization approaches, and main theoretical approach. Categories for characteristics assessed are detailed in Appendix S3. Some abstracts did not provide all necessary information and some of them have studied more than one environment or ecosystem. Then, the relative number of articles could be higher or lower considering each characteristic analyzed. We used chi-square tests to assess if there were differences between journals, considering the categories for each analyzed characteristic.

\section{RESULTS}

\section{GENERAL TRENDS OF LA SCIENTIFIC PUBLICATION}

Despite the low percentage of LA articles in relation to the total published articles in the journals obtained from the search on ISI's Web of Science ${ }^{\circledR}$ (maximum 9.3\%), Latin America scientific production in Ecology has been increasing. There was a prominent increase over the time span analyzed, but the faster increase occurred between 2000 and 2005 (Figure 1a). The most productive countries considering LA first authors were Brazil, Argentina, Mexico and Chile (Figure 1b). Despite the low production considering first authors between 2003 and 2004, Brazil showed the fastest growth (slope of linear regression $=0.52$ ). Argentina also showed increased scientific production (slope of linear regression $=0.39$ ), while other countries remained stable (Figure 1b).

In general, journals had low contribution of LA researchers (Figure 2). Furthermore, journals 

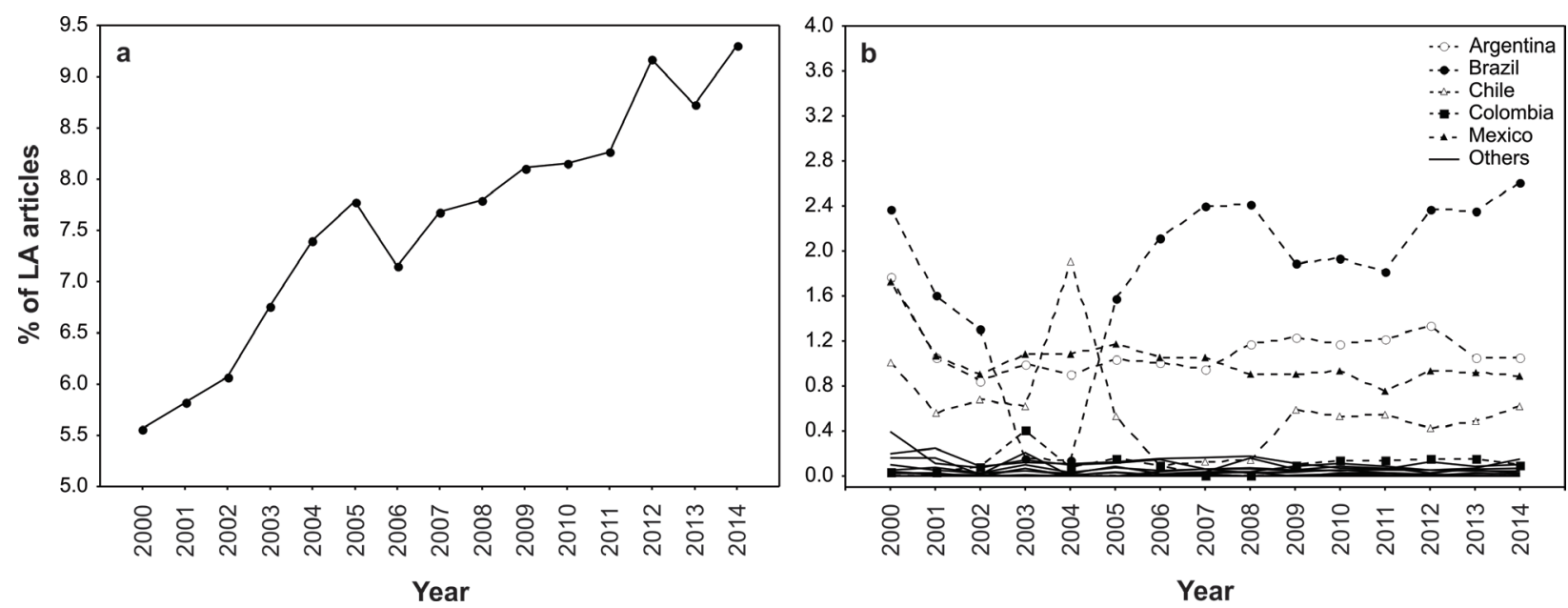

Figure 1 - Time series of ecological articles (in relation to the total number of articles published in the 80 selected journals) of Latin America as a whole (a) and of each Latin American country as first author (b).

with high Latin American participation had impact factors lower than five (Figure 2). "Biotropica" and "Journal of Tropical Ecology" were the journals in which Latin Americans published more (45.7\% and $37.8 \%$ of LA articles, respectively).

More than a half of LA publications had international collaboration (58\% of the articles). These collaborations were divided in NonLA-both: $34 \%$, LA-both: 18\%, LA-LA: 3\%, LA-NonLA: $2 \%$ and NonLA-LA: $1 \%$ of the total. By contrast, $42 \%$ of articles had no international co-authorship (LAnone).

The number of citations, after controlling for year of publication, is significantly related to coauthorship type (Figure 3a; $\mathrm{F}=119.4, P<0.001$ ) and number of authors (Figure $3 \mathrm{~b} ; \mathrm{F}=13.37, P$ $<0.001)$. NonLA-both was associated with more citations, followed by LA-both, LA-LA, LA-none, LA-NonLA and NonLA-LA (Absolute values of slopes: $-3.50,-2.93,-2.54,-2.49,-2.43$ and -1.99 , respectively). Considering the number of authors versus times cited, more than 5 authors had the highest absolute value of slope (-4.09) followed by 5, 2, 3, 4 and 1 author (Absolute values of slopes: $-2.85,-2.85,-2.83,-2.59$ and -2.16 , respectively).

\section{CHARACTERISTICS OF LATIN AMERICAN SCIENTIFIC PRODUCTION}

LA articles significantly differed between JTE and ECL considering the environment studied $\left(\chi^{2}=\right.$ 41.18 , d.f. $=3, P<0.001)$. Only one article dealt with marine environments in "Journal of Tropical Ecology", whereas freshwater ones were rarely focused on "Ecology Letters" (4 articles; Figure 4a). However, terrestrial environments were more studied in both journals $(74 \%$ and $88 \%$, respectively; Figure 4a).

The journals also differed regarding ecosystems $\left(\chi^{2}=133.28\right.$, d.f. $\left.=9, P<0.001\right)$. In both journals, the studies were carried out mostly in forests (Figure 4b), while lentic waters, arid and semiarid ecosystems, ocean and steppe were poorly studied (Figure 4b). Coastal shoreline ecosystems were recurrent on ECL, whereas savannah had higher publication numbers on JTE (Figure 4b). No articles dealt with steppe and ecotone forest-steppe on ECL.

JTE and ECL had the same characteristics when considering the ecological organization level of the researches $\left(\chi^{2}=1.5\right.$, d.f. $\left.=4, P>0.108\right)$. In both journals, communities were more studied followed by populations, ecosystems and individuals (Figure $4 c)$. 


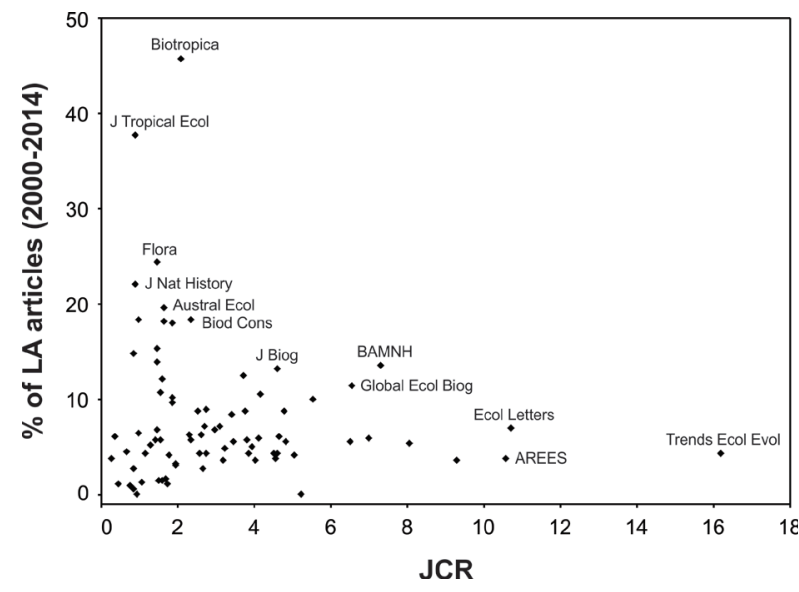

Figure 2 - Percentage of Latin American articles (from 2000 to 2014) considering the total number of papers from each journal against 2014 journal impact factors (JCR-2014). J Tropical Ecol $=$ Journal of Tropical Ecology; J Nat History $=$ Journal of Natural History; Austral Ecol = Austral Ecology; Biod Cons $=$ Biodiversity and Conservation; $\mathrm{J}$ Biog $=$ Journal of Biogeography; BAMNH = Bulletin of the American Museum of Natural History; Glob Ecol Biog = Global Ecology and Biogeography; Ecol Letters = Ecology Letters; AREES = Annual Review of Ecology and Systematics; Trends Ecol Evol $=$ Trends in Ecology and Evolution. For the full list of journals, corresponding impact factors, and the percentage of Latin American articles, see Appendix S2.

LA articles from these two journals differed considering the organism or variable focused $\left(\chi^{2}=\right.$ 31.44 , d.f. $=7, P<0.001)$. In both journals, studies focusing on plants were much more numerous, but particularly in JTE, followed by vertebrates and invertebrates (Figure 4d). No articles dealt with virus on JTE.

Surveys or observational studies were much more numerous in both journals in relation to other organization approaches (i.e., reviews, metaanalysis or methodological approaches; Figure 4e). However, JTE and ECL differed considering organization approaches $\left(\chi^{2}=114.48\right.$, d.f. $=6, P<$ $0.001)$ due to the higher number of surveys articles in JTE (almost 80\%) compared to ECL (less than $50 \%$ ), and the higher number of modeling articles in ECL (18\%) compared to JTE (1\%). There were few review and methodological articles published by LA authors in both journals. In addition, there were no meta-analysis on JTE (Figure 4e).
ECL and JTE also differed considering the main theoretical approach $\left(\chi^{2}=16.51\right.$, d.f. $=8$, $P<0.036)$. "Interactions" was the theoretical approach mostly considered in both journals, but particularly in ECL (Figure 4f). Articles focusing on "Community structure or fluctuation" and "Community assembly" were common in JTE, whereas "Disturbance" and "Population fluctuation or distribution range" were recurrent in ECL (Figure 4f).

\section{DISCUSSION}

\section{GENERAL TRENDS OF LA SCIENTIFIC PUBLICATION}

Latin America is passing through a process of increasing number of publications in Ecology. Although the development of Ecology as a formal discipline in Latin America is recent (Castillo and Toledo 2000, Martínez et al. 2006), the growth of ecological publications by Latin Americans is very similar to the observed in other traditional scientific fields (between 1988 and 2001, Hill 2004). Nevertheless, the LA contribution to Ecology is still small (less than $10 \%$ of ecological articles published per year; see Figure 1a). Considering that the Neotropical region (which comprises the Latin America) has unique characteristics and has been facing severe environmental threats, the growth is still unsatisfactory.

Previous studies have also shown that Brazil, Argentina and Mexico are among the LA countries with relatively high scientific expression (Stocks et al. 2008). Accordingly, these countries are among the largest economies in the region (World Bank 2007); besides, when compared to all countries in this region, they present the highest investment in scientific research (Macilwain 1999). High scientific production has been related to economic development (May 1997). However, LA science investments has not been growing at the same rate of publications (Hermes-Lima et al. 2007). 

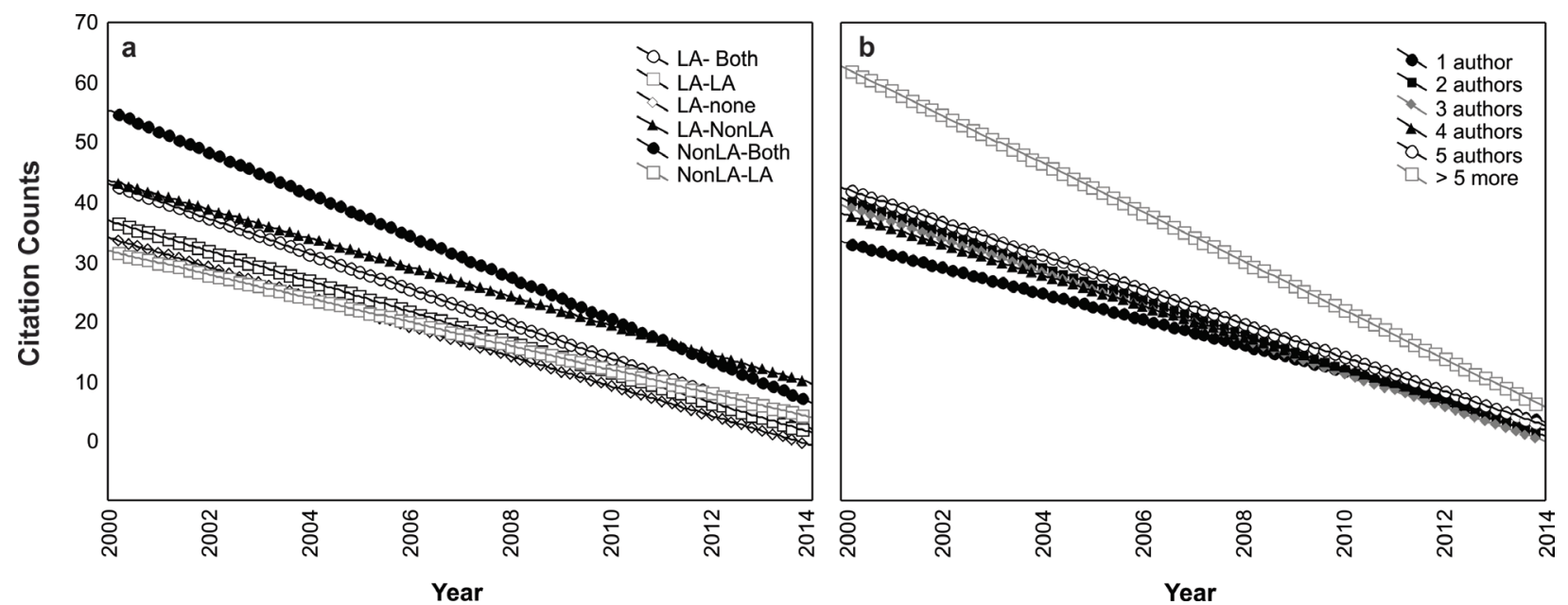

Figure 3 - Linear regression of citation counts of Latin American articles from 2000 to 2014 on (a) different cooperation types (see description above) and (b) number of authors.

Expenses in Latin America scientific research, relatively to the gross domestic product, are at least two fold smaller than in developed countries (Zenteno-Savín et al. 2007). Unfortunately, it seems that LA policy makers are not considering scientific research to solve their countries' problems (Martínez et al. 2006). This is particularly relevant for ecological publications, given that LA has high biodiversity of all biological groups, e.g., one of the highest species richness of vertebrates and plants in the planet (Myers et al. 2000), and investment in ecological science is thus central.

Participation of LA countries was smaller in high impact journals, as also has been found by other authors (see Stocks et al. 2008). We found higher LA participation in journals devoted to publish studies conducted in Tropical or Neotropical environments. Even so, LA researchers only authored $46 \%$ of the articles published in "Biotropica" and 38\% of the articles published in "Journal of Tropical Ecology", which only accept studies carried on tropical ecosystems. Thus, LA researchers presented relatively low scientific expression, even in tropical environments. The high percentage of articles in low impact journals seems to be a natural trend of nations with low scientific tradition, and are related to the quality/relevance of articles and/or social-psychological reasons (Meneghini et al. 2008). Additionally, this context feeds the vicious circle that affects the development of LA journals: local journals are relegated or viewed as simply recipients of manuscripts not accepted outside or with a high probability to be rejected in journals with high impact factors. This judgment might be due to a variety of reasons, including the authors' perceived value of the manuscript, the subject focused on local problems or interests, and language barriers (Packer 2001). Increases in the budgetary or human resources (see MoyaAnegón and Herrero-Solana 1999), theory-oriented studies, and advances in international cooperation (including with Latin American countries among themselves) may change this panorama and stimulate the development of Ecology as a science in the region.

The past decades experienced a strong increase in the international collaboration, as measured in internationally co-authored scientific publications (ISI 2007, Van Noorden et al. 2014). Unfortunately, this increase was lower in Ecology, which may be attributable to the less internationalization of biological sciences (Jappe 2007). Considering that environmental problems and related innovation needs are ubiquitous, international collaboration of 

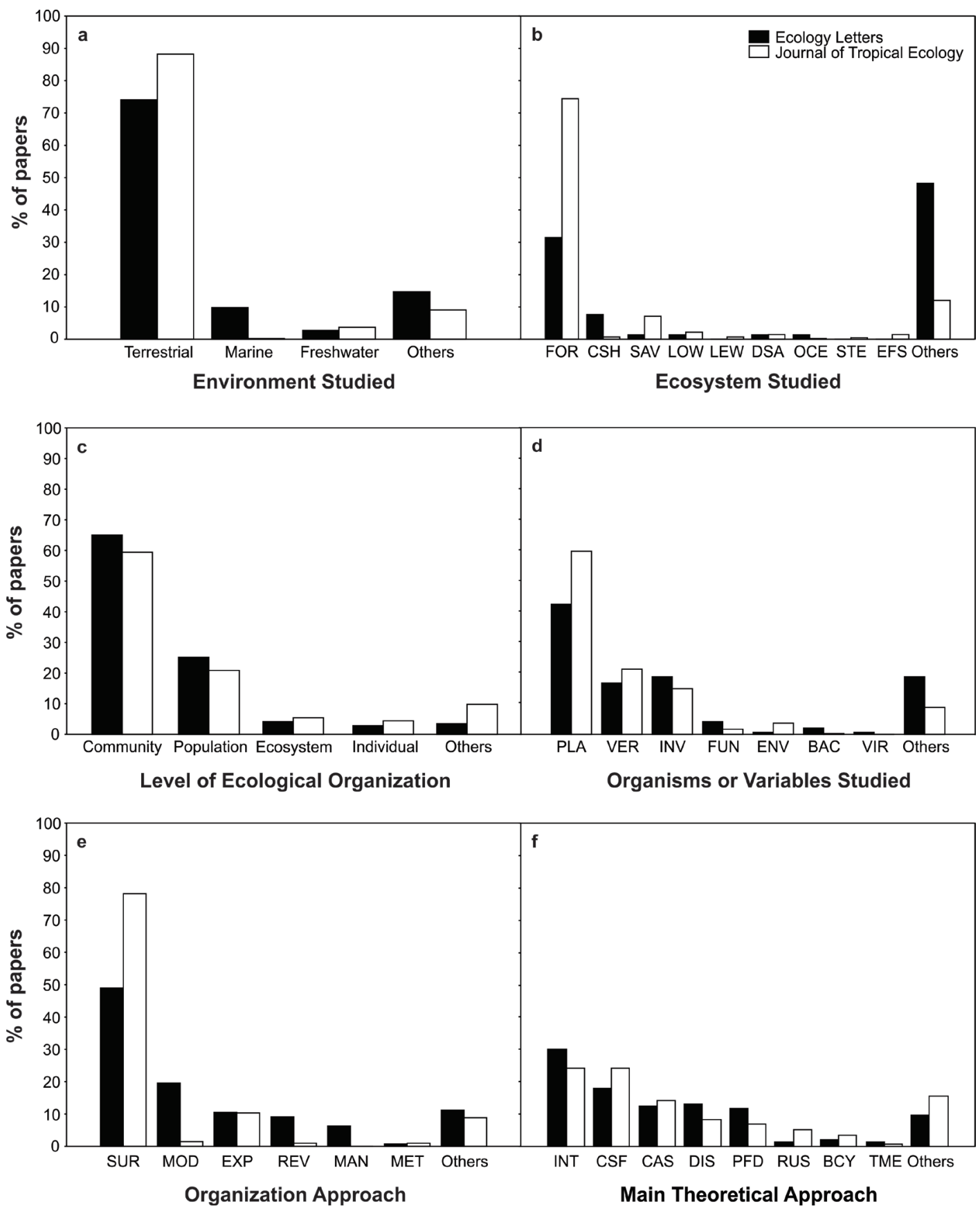

Figure 4 - Characteristics of ecological articles published by Latin Americans in Journal of Tropical Ecology and Ecology Letters. (a) Environments and (b) ecosystems mostly studied: FOR = Forests; CSH = Coastal Shoreline; $\mathrm{SAV}=$ Savannah; LOW = Lotic Waters; LEW = Lentic Waters; DSA = Deserts or Semi-Arid; OCE = Ocean; $\mathrm{STE}=$ Steppe; EFS = Ecotone Forest-Steppe; (c) Level of Ecological Organizations; (d) Organisms or variables: $\mathrm{PLA}=$ Plants; VER = Vertebrates; INV = Invertebrates; FUN = Fungus; ENV = Environmental variables; BAC = Bacteria; VIR = Virus; (e) Organization approaches: SUR = Survey; MOD = Modeling; EXP = Experimental; $\mathrm{REV}=$ Review; MAN = Meta-analysis; MET = Methodological approach; and (f) Main theoretical approaches: $\mathrm{INT}=$ Interactions; $\mathrm{CSF}=$ Community structure or fluctuation; CAS = Community assembly; DIS = Disturbance; $\mathrm{PFD}=$ Population fluctuation or distribution range; RUS = Resource use; $\mathrm{BCY}=$ Biogeochemical cycles; TME = Test of methods. For "Others", see Appendix S3. 
students and graduated researches must be improved to provide intellectual and financial support to Neotropical and undeveloped countries (Stocks et al. 2008). Here, we identified that international collaboration is central to improve visibility, and consequent citations, of articles authored by LA authors. The USA, England, and other Englishspeaking coutries have mostly cooperated with tropical countries in ecological studies (see also Melo et al. 2006, Padial et al. 2010, Stocks et al. 2008).

Accordingly, the effect of international cooperation on citations can also be partially responsible for our observation that more authors are associated to more citations. Probably, there is a positive correlation in our data between international cooperation and number of authors. A modern tendency is that all scientific fields become increasingly interdisciplinary, combining authors, oftentimes from different subareas (Nabout et al. 2015). Moreover, it is possible that the higher the number of authors, the larger the network of scientists that might know of one of them and, thus, cite them (Leimu and Koricheva 2005). However, it is also likely that international cooperation and numerous authors improve the quality of articles, explaining the increase in citation counts (Padial et al. 2010). Simultaneously, it seems that the relative number of single-authored biological papers is decreasing over the years (Nabout et al. 2015).

\section{CHARACTERISTICS OF LATIN AMERICAN} SCIENTIFIC PRODUCTION

Modest attention dispended to aquatic environments is startling in LA studies, since Neotropical marine and inland waters support a huge number of species (Agostinho et al. 2005). In addition, these environments are facing numerous anthropogenic threats and habitat degradation (Agostinho et al. 2005, Vitule et al. 2012). This result is similar to those found by Siqueira et al. (2015) who found that amongst 1,156 papers investigating species richness, $74 \%$ did that in terrestrial habitats whereas $21 \%$ addressed aquatic habitats. On the other hand, the predominance of studies performed in forests such as Amazon and Atlantic forests may be explained by the fact that they are the most diverse in the world (Myers et al. 2000). Another explanation could be that most of Brazilian research centers are located within the highly threatened Atlantic forest biome (see www.capes.gov.br). Studies carried on Savannahs were mostly due to the "Cerrado"; a Neotropical Savannah located in Brazil and one of the seven Latin American hotspots for biodiversity conservation (Myers et al. 2000). On the other hand, studies carried in arid and semi-arid ecosystems were present due to the extensive and biologically unique areas of Chilean and Argentinean deserts.

Once again, historical influences of Ecology may be partially responsible for the predominance of studies dealing with plants, since several pioneer studies focused on this biological group (Clements' and Cowles' publication about ecological succession). The term "Ecology" was first used in America by botanists (Real and Brown 1991). Besides, Eugene Warming carried important ecological studies in Brazil during the XIX century, mainly with amphibian and aquatic vegetation. Another explanation is that plants are sessile macroscopic organisms easy to manipulate, which facilitate ecological studies. It is also interesting to notice the scarcity of articles dealing with bacteria and fungus, organisms associated to important ecological processes such as nutrient cycling (see Figure 4d).

The predominance of studies at the community level indicated that Latin Americans were interested in understanding biodiversity (Figure $4 c)$. Indeed, community studies are essential to support biodiversity conservation and management of ecosystem functioning and must be encouraged, especially facing the increasing environmental threats in Latin America (Hardoy et al. 2010). 
The high percentage of observational studies (i.e., surveys, see Figure 4e) indicates that most LA investigations are still carried in a preliminary way, since surveys are the first step for scientific knowledge improvement (Kothari 2014). Indeed, hypotheses are firstly generated by observing the environment (Peters 1991), the assessment of these hypotheses could be done by (in situ or in vitro) experiments. Also, the low percentage of articles using modeling techniques, meta-analyses or reviews (mainly in JTE, see Figure 4e) highlighted the recent development of Latin Americans ecological researches. Situations like type II errors, isolated and presumably examples, and statistical significance emphasis are controlled and/ or reduced in a meta-analysis (Lajeunesse 2013), emphasizing the importance of these approaches for the development of science.

The most common theoretical approaches of LA articles were related to well-established theories (see Figure 4f). Studies had mostly a descriptive goal, suggesting that ecological researches carried by Latin Americans are still in the basic ground. However, this can be still a worldwide panorama, and recent and intriguing theories may be less studied than well-established theories.

By analyzing article-by-article, we could describe the main trends and gaps of ecological researches conducted by Latin Americans. This is essential to guide future researches in LA. Although journal profiles differed regarding its publication features, the overall characteristics were similar; the low number of theoretical studies and the predominance of descriptive researches suggest that ecological research in Latin America is slowly growing and has not yet reached the maturity.

\section{ACKNOWLEDGMENTS}

Suelen C.A. da Silva Pereto, Luis A.V. Bezerra, Fernanda Ceschin, and Juliana Wojciechowski received scholarships from Coordenação de
Aperfeiçoamento de Pessoal de Nível Superior (CAPES) and Jaqueline Dittrich from Conselho Nacional de Desenvolvimento Científico e Tecnológico (CNPq). André A. Padial also acknowledges $\mathrm{CNPq}$ for continuous financial supports. Tadeu Siqueira has been funded by grant \#2013/50424-1, Fundação de Amparo à Pesquisa do Estado de São Paulo (FAPESP). Authors acknowledge three anonymous reviewers for valuable suggestions in a previous draft.

\section{REFERENCES}

AGOSTINHO AA, THOMAZ SM AND GOMES LC. 2005. Conservation of the biodiversity of Brazil's inland waters. Conserv Biol 19: 646-652.

CALIXTO JB. 2005. Twenty-five years of research on medicinal plants in Latin America. J Ethnopharmacol 100: 131-134.

CASTILLO A AND TOLEDO VM. 2000. Applying ecology in the third world: The case of Mexico. BioScience 50: 66 .

CATANZARO M, MIRANDA G, PALMER L AND BAJAK A. 2014. South American science: Big players. Nature 510: 204-206.

FALAGAS ME, KARAVASIOU AI AND BLIZIOTIS IA. 2006. A bibliometric analysis of global trends of research productivity in tropical medicine. Acta Trop 99: 155-159.

GALINDO-LEAL C. 2000. Conservation science in Latin America. Interciencia 25: 129-135.

GINGRAS Y, LARIVIÈRE V, MACALUSO B AND ROBITAILLE JP. 2008. The effects of aging on researchers' publication and citation patterns. PLoS ONE 3: e4048.

GLÄNZEL W, LETA J AND THIJS B. 2006. Science in Brazil. Part 1: A macro-level comparative study. Scientometrics 67: 67-86.

GODWIN H. 1977. Sir Arthur Tansley: the man and the subject. J Ecol 65: 1-26.

HARDOY JE, MITLIN D AND SATTERTHWAIT D. 2010. Environmental problems in an urbanizing world: Finding solutions to cities in Africa, Asia and Latin America. Earthscan, London and Washington, DC, 448 p.

HERMES-LIMA M AND NAVAS CA. 2006. The face of Latin American comparative biochemistry and physiology. Comp Biochem Phys C 142: 157-162.

HERMES-LIMA M, SANTOS NCF, ALENCASTRO ACR AND FERREIRA ST. 2007. Whither Latin America? trends and challenges of science in Latin America. IUBMB Life 59: 199-210. 
HILL DL. 2004. Latin America shows rapid rise in S\&E articles. Division of Science Resources Statistics Science Re, p. 1-9. IN-CITES. 2006. 10-Year Country Rankings for: Brazil.

ISI. 2007. ISI Web of knowledge, Web of Science.

JAPPE A. 2007. Explaining international collaboration in global environmental change research. Scientometrics 71: 367-390.

KOTHARI CR. 2014. Research methodology: methods \& techniques ( $3^{\text {rd }}$ edition). New Age International, New Delhi, $418 \mathrm{p}$.

LAJEUNESSE MJ. 2013. Recovering missing or partial data from studies: A survey of conversions and imputations for Meta-Analysis. p. 497. In: Koricheva J, Gurevitch J and Mengersen K (Eds), Handbook of Meta-analysis in Ecology and Evolution. Princeton University Press, Princeton and Oxford.

LEIMU R AND KORICHEVA J. 2005. What determines the citation frequency of ecological papers? Trends Ecol Evol 20: $28-32$

MACILWAIN C. 1999. Stability offers unique opportunity for research. Nature 398: 4-5.

MARTÍNEZ ML, MANSON RH, BALVANERA P, DIRZO R, SOBERÓN J, GARCÍA-BARRIOS L, MARTÍNEZRAMOS M, MORENO-CASASOLA P, ROSENZWEIG L AND SARUKHÁN J. 2006. The evolution of ecology in Mexico: Facing challenges and preparing for the future. Front Ecol Environ 4: 259-267.

MAY RM. 1997. The scientific wealth of nations. Science 275: 793-796.

MELO AS, BINI LM AND CARVALHO P. 2006. Brazilian articles in international journals on Limnology. Scientometrics 67: 187-199.

MENEGHINI R, PACKER AL AND NASSI-CALÒ L. 2008. Articles by latin american authors in prestigious journals have fewer citations. PLoS ONE 3: e3804.

MOYA-ANEGÓN F AND HERRERO-SOLANA V. 1999. Science in america latina: A comparison of bibliometric and scientific-technical indicators. Scientometrics 46: 299-320

MYERS N, MITTERMEIER RA, MITTERMEIER CG, DA FONSECA GAB AND KENT J. 2000. Biodiversity hotspots for conservation priorities. Nature 403: 853858.

NABOUT JC, PARREIRA MR, TERESA FB, CARNEIRO FM, DA CUNHA HF, DE SOUZA ONDEI L, CARAMORI SS AND SOARES TN. 2015. Publish (in a group) or perish (alone): the trend from single- to multiauthorship in biological papers. Scientometrics 102: $357-$ 364.

NUNES ED. 2006. A trajetória das ciências sociais em saúde na América Latina: revisão da produção científica. Rev Saúde Pública 40: 64-72.
PACKER AL. 2001. The SciELO model for electronic publishing and measuring of usage and impact of Latin American and Caribbean scientific journals. p. 1-4. Proceedings of the Second ICSU-UNESCO International Conference on Electronic Publishing in Science. Paris.

PADIAL AA, NABOUT JC, SIQUEIRA T, BINI LM AND DINIZ-FILHO JAF. 2010. Weak evidence for determinants of citation frequency in ecological articles. Scientometrics 85: $1-12$.

PELLEGRINI FILHO A, GOLDBAUM M AND SILVI J. 1997. Production of scientific articles on health in six Latin American countries, 1973-1992. Rev Panam Salud Publ 2: 121-132.

PETERS RH. 1991. A critique for Ecology ( ${ }^{\text {st }}$ edition). Cambridge University Press, Cambridge, 366 p.

REAL LA AND BROWN JH. 1991. Foundations of Ecology: Classic papers with commentaries ( $1^{\text {st }}$ edition). University of Chicago Press, Chicago, 920 p.

SIQUEIRA T, BINI LM, THOMAZ SM AND FONTANETO D. 2015. Biodiversity analyses: are aquatic ecologists doing any better and differently than terrestrial ecologists? Hydrobiologia 750: 5-12.

STOCKS G, SEALES L, PANIAGUA F, MAEHR E AND BRUNA EM. 2008. The geographical and institutional distribution of ecological research in the tropics. Biotropica 40: 397-404.

TOLEDO VM AND CASTILLO A. 1999. Ecology in Latin America: Seven thesis for a pertinent science in a region in crisis. Interciencia 24: 157-168.

VAN NOORDEN R. 2014. The impact gap: South America by the numbers. Nature 510: 202-203.

VERBEEK A, DEBACKERE K, LUWEL M AND ZIMMERMANN E. 2002. Measuring progress and evolution in science and technology - I: The multiple uses of bibliometric indicators. Int J Manag Rev 4: 179-211.

VITULE JRS, LIMA JUNIOR DP, PELICICE FM, ORSI M AND AGOSTINHO AA. 2012. Preserve Brazil's aquatic biodiversity. Nature 485: 309.

WEISINGER JR AND BELLORÍN-FONT E. 1999. Latin American nephrology: scientific production and impact of the publications. Kidney Int 56: 1584-1590.

WORLD BANK. 2007. World Development Indicators database 2007.

ZENTENO-SAVÍN T, BELEBONI RO AND HERMESLIMA M. 2007. The cost of Latin American science. Introduction for the second issue of CBP-Latin America. Comp biochem phys A 146: 463-469.

\section{SUPPLEMENTARY MATERIAL}

Appendix S1 - List of countries considered in the analyses of participation of LA authors in the field of Ecology from 2000 
to 2014. These countries returned publications in journals indexed by ISI's Web of Science ${ }^{\circledR}$, within the "Ecology" subject category, and were alphabetic organized by region (South America, Caribbean and Central America).

Appendix S2 - List of journals obtained from the search on Thomson-ISI, their corresponding impact factor (JCR-2014), total of articles published by each journal from 2000 to 2014, number of articles with at least one Latin American author per journal (LA articles) and percentage of LA articles in relation to total (\% LA articles).

Appendix S3 - Characteristics and categories used to compare Latin American articles published in "Ecology Letters" and

“Journal of Tropical Ecology" between 2000 and 2014. 